\title{
Yksilön toimijuudesta yhteiseksi käytännöksi
}

\author{
Muutospajat oppilaitoksen ja \\ työpaikkojen välistä yhteistyötä \\ rakentamassa
}

\begin{abstract}
$+y$
Toimiva työelämäyhteistyö on ammatillisille oppilaitoksille olennainen kysymys, jotta opiskelijoita voidaan valmentaa tulevaisuuden

työhön. Muutospaja toimii oppilaitoksen ja työpaikkojen yhteistyökäytäntöjen rakentajana ja yhteisen kehittämistoimijuuden virittäjänä, mutta verkostomaisissa interventioissa tulisi tukea entistä enemmän osallistujien yksilöllistä kehittämistoimijuutta. Näin kokeilut muuttuvat kestävämmiksi käytännöiksi.
\end{abstract}

$\mathbf{y}$

TOISEN ASTEEN AMMATILLISEN koulutuksen haasteena on erityisesti 2010-luvulta lähtien ollut vastata yhä paremmin ja ajantasaisemmin muuttuvan työelämän osaamistarpeisiin. Koska työ ja osaamisvaatimukset ovat voimakkaassa murroksessa muun muassa teknologisen kehityksen myötä, tuorein, vuonna 2018 toteutettu ammatillisen koulutuksen reformi on vienyt oppimisen painopistettä voimakkaasti oppimiseen työelämässä (Amistutkimus 2018).
Samaan aikaan työn muutos ja kiristyvät tuottavuusvaatimukset työpaikoilla ja niiden mukanaan tuoma kiire on tunnistettu työpaikalla tapahtuvan ohjauksen suurimmaksi esteeksi (Rintala, Mikkonen, Pylväs, Nokelainen \& Postareff 2015). Yleisenä huolena on esitetty, ovatko työpaikkojen aika- ja henkilöresurssit riittäviä työpaikkaohjauksen vaativaan tehtävään ja oppimisen laadusta huolehtimiseen (Töytäri, Tynjälä, Vanhanen-Nuutinen, Virtanen \& Piirainen 2019). 
Ammatillisten opettajien haaste on ammatillisen koulutuksen uudistuksen myötä siirtyä oppilaitoskeskeisestä opetustyöstä kohti verkostotoimijuutta, jossa tarvitaan koulutuksen ja työelämän molemminpuolista ymmärrystä, sitoutumista ja luottamusta (Laajala 2016). Ammatillisen opettajan uudeksi osaamisvaatimukseksi nousee opiskelijoiden ja työpaikkojen tarpeiden yhteensovittaminen, suhteiden ja uusien yhteistyökäytäntöjen luominen oppilaitoksen ja työelämän välille (Lehtonen, Rintala, Pylväs \& Nokelainen 2018).

Oppilaitosten ja työelämän välistä yhteistyötä käsittelevissä tutkimuksissa on kuitenkin tunnistettu eräänlainen toimijuuksien keskinäinen epäsuhta. Vastuu yhteistyön organisoinnista ja toteutuksesta on jäänyt valtaosin oppilaitosten opettajille, ja yhteistyötä on tehty oppilaitosten ehdoilla (Jokinen, Lähteenmäki \& Nokelainen 2009, 34).

Oppilaitoksen ja työpaikan yhteistyö voisi parhaimmillaan tukea sekä oppijan yksilöllistä että ympäröivän käytäntöyhteisön oppimista. Opiskelija voisi toimia rajanylittäjänä, joka tuo aineksia formaalista oppimisesta työpaikalle ja samalla oppii, miten toimia käytäntöjen muuttajana (Gherardi, Nicolini \& Odella 1998; Guile \& Griffiths 2001; Filliettaz 2011). Opettajat ovat ammatillisen koulutuksen arjessa tunnistaneet tärkeäksi tavoitteekseen rakentaa yhteistyötä työelämän kanssa, mutta vastavuoroisen oppimiskumppanuuden ja yhteistyön aikaansaaminen on käytännössä ollut harvinaista (Laajala 2016; Vanhanen-Nuutinen \& LaitinenVäänänen 2018).

Tutkimme artikkelissamme pyrkimystä rakentaa oppilaitoksen, opiskelijan ja työpaikan välille työelämässä oppimiselle edellytyksiä luova yhteistyökäytäntö. Toteutimme kehittävään työntutkimukseen pohjautuvan muutospajaintervention (Virkkunen \& Newhamn, 2013), joka kokosi oppilaitoksen ja työpaikan eri toimijat sekä opiskelijat yhdessä kehittämään yrittäjän ammattitutkintoon liittyvää, oppilaitoksen ja työpaikkojen välistä yhteistyötä. Interventiomme liikkeellepaneva jännite oli, kuinka rakentaa yhteistyötä niin, että opiskelija pystyisi oppimaan osallistumalla nykyiseen työhön työpaikalla ja saisi samalla mahdollisuuden kehittää työkäytäntöjä vas- taamaan työn tulevia haasteita. Tutkimuskysymyksemme ovat seuraavat:

1) Millaista kehittämistoimijuutta muutospajainterventio synnytti monitoimijaisessa verkostossa?

2) Miten yksilön aloitteet ja muutospajassa yhdessä käyty yhteinen keskustelu rakentuivat suhteessa toisiinsa?

3) Miten kestäviä kehittämistoimijuus ja syntynyt kokeilu olivat intervention jälkeen?

Keskitymme analyysissämme yhteen ja ainoaan intervention tuottamaan kokeiluun sekä aktiivisimmin toimineen kouluttajan puheisiin ja tekoihin intervention kuluessa ja sen jälkeen. Yksilön ja yhteisön toimijuuden suhdetta kehittämisinterventiossa ei ole juuri tutkittu empiirisesti (Kerosuo 2014), vaikka niiden välinen jännite on sinänsä tunnistettu sosiaalitieteellisen toimijuustutkimuksen piirissä. Verkostomainen kehittämisinterventio kytkeytyy eri tavoin kunkin mukana olevan organisaation toimintaan. Kullakin interventioon osallistuneella on potentiaalinen muutosagentin rooli omassa organisaatiossaan. Jotta ymmärretään yhä paremmin kehittämisen dynamiikkaa verkostomaisessa interventiossa, on perusteltua seurata yksilön aloitteita ja kehittämistekoja intervention aikana. Koska intervention seuraukset kohdistuvat potentiaalisesti monen organisaation toimintatapoihin, on lisäksi perusteltua seurata, miten kukin osallistuja vie kehittämistekoja omaan toimintaansa.

\section{OPPIMINEN UUDEN LUOMISENA SEKÄ YKSILÖLLISEN JA YHTEISÖLLISEN KEHITTÄMISTOIMIJUUDEN RAKENTUMISENA}

Perinteinen tapa ymmärtää, mitä on oppiminen, on nähdä se eräänlaisena tiedon tai taidon kuljetuksena osaavalta opettajalta tai kirjoista oppijalle, jolta puuttuu osaamista. Sosiokulttuurisessa lähestymistavassa opiskelija ajatellaan ammatillisen koulutuksen asetelmassa rajanylittäjäksi, jonka omaksuma tuorein teoriatieto voi auttaa työyhteisöä uudistamaan työtä (Engeström 1994). Työelämässä oppiminen näin 


\section{TOIMIJUUS EI OLE}

\section{VAPAASTI VALITTAVISSA, \\ VAAN SIT $\ddot{A}$ KEHYST $\ddot{A} V \ddot{A T}$}

\section{VALTASUHTEET JA}

\section{TOIMINTAMAHDOLLISUUDET.}

nähtynä ei ole vain uusien työn vaatimien taitojen omaksumista vaan sellaisen uudenlaisen identiteetin ja toimijuuden rakentamista, joka pystyy muuttamaan sitä toimintaa, jonka osaksi toimija samalla kasvaa (Gherardi, Nicolini \& Odella 1998).

Sosiokulttuurisessa lähestymistavassa on painotuseroja sen suhteen, ajatellaanko yksilöllinen ja sosiaalinen analyyttisesti erillisiksi. Kaikille niille on yhteistä nähdä toimijuuden kehittyvän tilanteisesti ihmisten, diskurssien, käytäntöjen ja materiaalisten artefaktien välisissä yhteen kietoutuvissa prosesseissa (Gherardi 2018, 40). Metodinen valintamme on analysoida oppimista ja toimijuutta toinen toisiinsa vaikuttavina sekä yhteisöllisenä että yksilöllisenä puheen ja tekojen ilmentymänä (Eteläpelto, Vähäsantanen, Hökkä \& Paloniemi 2014).

Yleensä sosiaalitieteellisessä kirjallisuudessa 'toimijuudella' viitataan yksilön mahdollisuuksiin vaikuttaa omaan elämäänsä rakenteiden ja instituutioiden rajatessa toimintaa. Samalla käsite sisältää yksilön mahdollisuuden ylittää näitä toiminnan kehyksiä tietoisilla teoilla (Emirbayer \& Mische 1998).

Opiskelijan oma toimijuus on olennainen oppimista edistävä asia. Se ilmenee tekoina, joilla opiskelija osoittaa olevansa aloitteellinen ja tavoitteellinen ja joilla hän ottaa hallintaansa työtilanteita ja ympäristöjä. Samalla toimijuuteen vaikuttaa konteksti, joissa tekoja tehdään, kuten kuinka legitiimi ja vaikuttava rooli tulokkaalle annetaan ja mahdollistaako se itseohjautuvuuden ja itsenäisyyden marginaalisen aseman sijaan (Eteläpelto 2017; Rintala \& Nokelainen 2019, Gherardi, Nicolini \& Odella 1998).

Verkottuneessa työelämässä oppimista tapahtuu organisaatioiden välissä sekä käytäntöjen ja kokeilujen välisessä kudelmassa, jossa työn kehittämisestä tulee keskeinen oppimisen muoto ja verkostossa liikkujasta erilaisten käytäntöjen yhteen kutoja tai törmäyttäjä (Ahonen, Virolainen \& Gardemaister 2020). Parhaimmillaan ammatilliset opettajat ovat oppimisen uusien käytäntöjen kutojia yhdessä työpaikkojen kanssa. Heidän olisi mahdollista ravistella epävirallisia valtasuhteita työpaikalla sekä rakentaa uutta oppimisen ja toimijuuden mahdollisuutta opiskelijoille vaikuttamalla työpaikkojen oppimiskäytäntöihin. Aiemmissa tutkimuksissa on havaittu, että opettajien oppimiskäsityksissä elää sitkeästi se ajatus, että luokkahuoneessa oppija on kohde eikä aktiivinen toimija (Laajala 2016, 300).

Yhteisön toiminnan muuttaminen edellyttää yksilöltä toimivaltaa, mahdollisuutta vaikuttaa - siis toimijuutta, lupaa ja valtaa muuttaa yhteistä käytäntöä (Saari, Hasu, Käpykangas \& Kovalainen 2020). Toimijuus ei siten ole vapaasti valittavissa, vaan sitä kehystävät valtasuhteet ja omat toimintamahdollisuudet tietyissä oloissa (Eteläpelto 2017). Analyysissä pohdimme seuraavia tekijöitä, jotka vaikuttavat yksilön toimijuuteen: kouluttajan työhistoria, ammatti-identiteetti ja kokemus mahdollisuuksista vaikuttaa sekä oppimiskäsitys. Tunnistamme myös ne yhteisön vaikutuspiirissä kehittyneiksi.

Muutospajan oppimiskäsitys nojaa ekspansiivisen oppimisen teoriaan, jossa oppiminen nähdään laajemmin kuin vain uuden tiedon omaksumisena. Oppimista pidetään yhteisössä tapahtuvana, ristiriitojen kautta kehittyvänä yhteisesti rakentuvana uuden luomisen prosessina (Engeström 1987). Kehittävän työntutkimuksen interventioiden yhteydessä toimijuutta on tutkittu pääosin kollektiivisena toimijuutena. Käsitteinä on käytetty transformatiivista toimijuutta tai muutostoimijuutta, jota tässä yhteydessä kutsumme 'kehittämistoimijuudeksi' (Haapasaari 2020). Se viittaa osallistujien yksilöllisesti alulle panemaan ja yhteiseen aloitteelliseen toimintaan, kun he murtautuvat nykyisen toiminnan kehyksistä kohti tulevaa ja rakentavat yhdessä aiempaa kehittyneempää toimintamallia (Haapasaari, Engeström \& Kerosuo 2014).

Kehittämistoimijuutta on tutkittu ja edistetty kehittävän työntutkimuksen niin sanotuissa muutoslaboratorio-interventioissa, joissa on viritetty erityisesti osallistujien yhteistä oppimista (Engeström 2007). 


\begin{tabular}{|c|c|}
\hline Yksilöllinen toimijuus & Yhteisöllinen kehittämistoimijuus \\
\hline \multirow{7}{*}{$\begin{array}{l}1 \text { Oman toimijuuden } \\
\text { asemointi ja merkitys } \\
\text { Omien toiminta- } \\
\text { mahdollisuuksien pohdinta, } \\
\text { oman roolin rajaus tai } \\
\text { laajentaminen suhteessa } \\
\text { muutokseen }\end{array}$} & $\begin{array}{l}2 \text { Johdon ja kehittäjien vastustaminen } \\
\text { Johdon tai intervention fasilitoijan kritisointi, kyseenalaistaminen, vastustaminen } \\
\text { tai huomiotta jättäminen }\end{array}$ \\
\hline & $\begin{array}{l}3 \text { Nykyisen toiminnan kritisointi ja muutostarve } \\
\text { Toiminnan muutostarpeen pohdinta, ongelmien tunnistus ja niiden kritisointi }\end{array}$ \\
\hline & $\begin{array}{l}4 \text { Toiminnan uusien mahdollisuuksien selittäminen } \\
\text { Vanhan toimintatavan potentiaalin tunnistaminen ja sen ongelmien näkeminen } \\
\text { uudenlaisena mahdollisuutena }\end{array}$ \\
\hline & $\begin{array}{l}5 \text { Toiminnan uusien toimintatapojen tai -mallien visualisointi ja suunnittelu } \\
\text { Uudenlaisen mallin ehdottaminen tai tulevan toimintamallin muotoilu }\end{array}$ \\
\hline & $\begin{array}{l}6 \text { Sitoutuminen toimintaa muuttaviin tekoihin } \\
\text { Sitoutumisen ilmaiseminen tuleviin tekoihin }\end{array}$ \\
\hline & $\begin{array}{l}7 \text { Tekeminen ja toimiminen työn muuttamiseksi } \\
\text { Tekojen ja kokeilujen suorittaminen intervention kuluessa }\end{array}$ \\
\hline & $\begin{array}{l}8 \text { Uuden käytännön vakiinnuttaminen intervention jälkeen } \\
\text { Käytännön levittäminen laajemmin kuin kokeiluina, jatkuvuudesta huolehtiminen } \\
\text { erilaisin teoin }\end{array}$ \\
\hline
\end{tabular}

Taulukko 1. Kehittämistoimijuuden analyysikehikko.

Tutkimus on keskittynyt pääosin intervention aikaiseen, osallistujien välisen keskustelun ja toiminnan lähikehityksen yhteiseen oivaltamiseen eikä niinkään siihen, millaisia tekoja yksilöt ovat intervention seurauksena tehneet omissa yhteisöissään (Kerosuo 2014, Haapasaari 2020).

Keskeinen interventioissa käytetty käsite on ollut 'toiminnan lähikehityksen vyöhykkeen' tunnistaminen, jolla viitataan nykyisen tilanteen ja nykyisen toiminnan jännitteet ratkaisevan potentiaalisen toimintamallin väliseen alueeseen (Vygotsky 1986). Lähikehityksen vyöhykettä mallinnettiin muutospajassa niin sanotun kehityskartan avulla (Ahonen, Virolainen \& Gardemeister 2020). Se auttaa interventioon osallistuvia yhdessä tarkastelemaan asiakkaiden ja toimintatapojen muutosta ja siten luomaan yhteistä näkymää toiminnan kehityksestä.

Aiemmissa muutoslaboratoriointerventioissa tunnistetut, osallistujayhteisössä tapahtuvat teot (taulukko 1, teot 2-7) noudattelivat ekspansiivisen oppimisen vaiheita (Haapasaari, Engeström \& Kerosuo 2014). Kehitysvuoropuhelua ammatillisen kehityksen interventiona tutkiessaan Heikkilä ja Seppänen (2014) analysoivat kehittämistoimijuutta yksilön näkökulmasta. He löysivät aineistosta kehittämisteon, toimijuuden uudelleen määrittämisen, jossa puheen kohteena olivat yksilön omat toimintamahdollisuudet ja omien tekojen suuntaaminen. Toimijuuden määrittäminen muistuttaa itsensä asemointia suhteessa muutokseen, jossa tunnistetaan oma rooli muutoksessa ja jossa etsitään yhteisymmärrystä toisten kanssa (Gorli, Nicolini \& Scaratti 2015).

Muodostimme tästä yksilön roolia kuvaavasta teosta oman toimijuuden asemointi ja merkitys -teon analyysikehikkoomme. Koska keräsimme aineistoa myös noin vuosi intervention jälkeen, lisäsimme viimeiseksi luokaksi (teko 8) uuden käytännön vakiinnuttamista koskevat teot, mikä viittaa ekspansiivisen oppimisen viimeiseen vaiheeseen. Näin muodostunut analyysikehys (taulukko 1) sisältää yksilöllisen toimijuuden asemoinnin kulkevan ekspansiivista oppimista mukailevien yhteisöllisten kehittämistekojen rinnalla. 


\section{AINEISTO JA ANALYYSIMENETELMÄT}

Tutkimusaineisto kerättiin muutospajaprosessista (kuva 1), jonka toteutimme vähittäiskaupan alalla toimivan yrityksen ja ammatillisen oppilaitoksen yhteistyön vahvistamiseksi lokakuusta 2018 huhtikuuhun 2019. Yritys ja oppilaitos olivat jo ennen muutospajoja tehneet yhteistyötä yrittäjän ammattitutkintoon tähtäävän koulutuskokonaisuuden järjestämisessä, mutta opiskelijoita ohjaavien kasvattajakauppiaiden ja kouluttajien välinen yhteistyö oli vielä vähäistä. Muutospajan tavoite oli rakentaa tulevaisuuden ammattilaisten kehittymistä tukevaa yhteistyötä ja kokeilla sitä käytännössä.

Muutospaja perustuu kehittävän työntutkimuksen teoriaan ja metodologiaan, sekä muutoslaboratorio (C)-menetelmään (Engeström 1987; Virkkunen \& Newnham 2013). Se suuntaa huomion kehittyvään työhön ja uudistuviin osaamistarpeisiin. Se pyrkii vahvistamaan uutta luovaa oppimista ja osallistujien kehittämistoimijuutta tarjoamalla areenan, jossa voidaan kokeilla yhdessä ja keskustella yhteistyön merkityksestä eri toimijoille
(Virkkunen \& Newnham 2013; Edwards 2012).

Muutospajassa fasilitoijat tukevat osallistujien kehittämistoimijuutta kahden virikkeen menetelmällä (Vygotsky 1978). Ensimmäisen virikkeen muodostaa aineisto, joka tuo esiin kaupan arkityön ja toimijoiden yhteistyön pulmallisia tilanteita. Toisena virikkeenä toimivat fasilitoijan tarjoamat mallit ja jäsennykset, jotka auttavat tarkastelemaan arjen pulmatilanteita aiempaa laajemmassa kontekstissa sekä tunnistamaan nykytoiminnan jännitteitä, joita arjen pulmat ilmentävät (Engeström 1987).

Pääaineistomme koostuu neljästä ääninauhoitetusta ja litteroidusta muutospajakeskustelusta, joista kukin kesti kolme tuntia. Osallistujat antoivat kirjallisen suostumuksensa keskustelujen nauhoittamiseen tutkimusaineistoksi. Muutospajassa yrityksen ja oppilaitoksen toimijat keskustelivat tutkijoiden fasilitoimana vähittäiskaupan alan muutoksesta ja yrittäjän uudistuvista osaamistarpeista, nykyisistä yrityksen ja oppilaitoksen yhteistyökäytännöistä sekä tuottivat tulevaisuuden yhteistyötä rakentavia kokeiluja ja arvioivat niistä opittua. Artikkelin toinen ja kolmas kirjoittaja toimivat muutospajojen fasilitoijina.

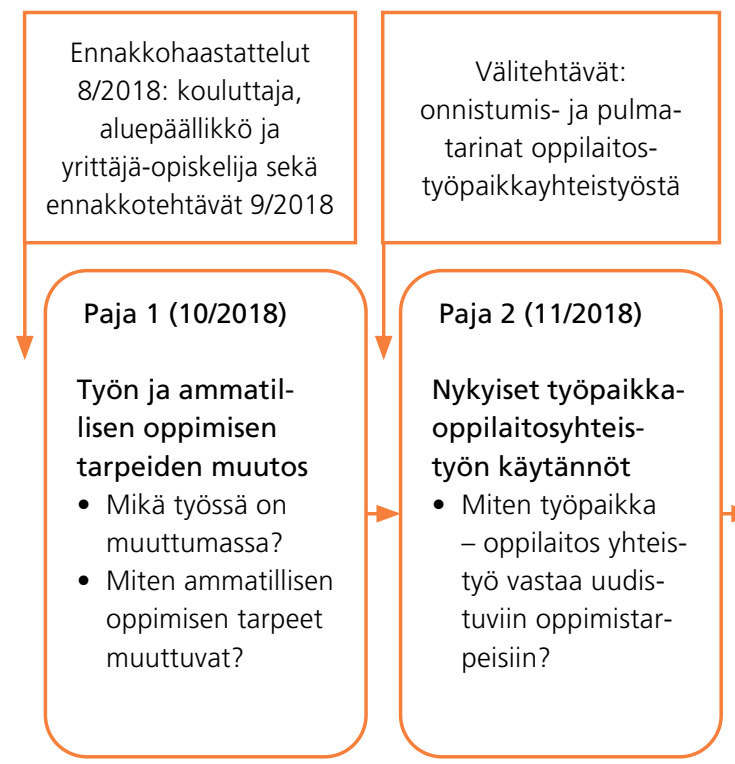

Analyysivaihe

Tulkintavaihe

Kuva 1. Muutospaja ja kerätty aineisto. 


\begin{tabular}{|c|c|c|c|c|}
\hline & Paja 1 & Paja 2 & Paja 3 & Paja 4 \\
\hline Ryhmä 1 & $\begin{array}{l}\text { Kauppias-yrittäjä } \\
\text { Opiskelija A } \\
\text { HR-toimija B }\end{array}$ & $\begin{array}{l}\text { Kouluttaja V } \\
\text { Kouluttaja B } \\
\text { Terveydenhuollon } \\
\text { kouluttaja }\end{array}$ & $\begin{array}{l}\text { Kouluttaja V } \\
\text { Kauppias-yrittäjä } \\
\text { Aluepäällikkö } \\
\text { Opiskelija A }\end{array}$ & $\begin{array}{l}\text { Kouluttaja V } \\
\text { HR-toimija B } \\
\text { HR-toimija C }\end{array}$ \\
\hline Ryhmä 2 & $\begin{array}{l}\text { Kasvattaja-kauppias } \\
\text { Opiskelija B } \\
\text { HR-toimija A } \\
\text { Kouluttaja B }\end{array}$ & $\begin{array}{l}\text { Kauppias-yrittäjä } \\
\text { HR-toimija A } \\
\text { HR-toimija C }\end{array}$ & $\begin{array}{l}\text { Kasvattaja-kauppias } \\
\text { Opiskelija B } \\
\text { HR-toimija B } \\
\text { HR-toimija D } \\
\text { Kouluttaja B }\end{array}$ & $\begin{array}{l}\text { Kasvattaja-kauppias } \\
\text { Kouluttaja B }\end{array}$ \\
\hline Ryhmä 3 & $\begin{array}{l}\text { Aluepäällikkö } \\
\text { Opiskelija C } \\
\text { HR-toimija C }\end{array}$ & $\begin{array}{l}\text { Opiskelija B } \\
\text { Opiskelija C }\end{array}$ & - & - \\
\hline Osallistujamäärä & 10 henkilöä & 8 henkilöä & 9 henkilöä & 5 henkilöä \\
\hline
\end{tabular}

Taulukko 2. Muutospajan osallistujat ja ryhmäjaot. Harmaalla on merkitty ryhmät, joista tehtiin tarkempi kehittämistekojen analyysi.

Pajoihin osallistui 13 henkilöä, ja ryhmien kokoonpanot vaihtelivat pajasta toiseen (taulukko 2). Osallistujat edustivat jo valmistuneita opiskelijoita, johtoa, kauppiaita, henkilöstöhallinnon toimijoita (HR) ja kouluttajia. Seitsemän henkilöä osallistui vähintään kolmeen pajaan. Ainoastaan yksi henkilö, toinen kouluttajista, osallistui kaikkiin pajoihin.

Lisäksi aineistoina olivat kolmen muutospajaosallistujan ennakkohaastattelut, yhden osallistujan jälkihaastattelu vuosi muutospajaprosessin jälkeen, pajojen esitysmateriaalit ja ryhmätöiden tuotokset sekä ennakko- ja välitehtävät.

Aineiston analyysi oli sekä teoria- että aineistolähtöistä. Aineisto analysoitiin ensimmäisen kirjoittajan johdolla. Ensin hän kuunteli kaikki pajanauhoitteet ja luki niiden litteraatiot läpi. Sen jälkeen keskustelimme yleisistä havainnoista ja päädyimme keskittymään analyysissä pajojen 2 ja 3 ryhmäkeskusteluihin ja muutospajojen tuottamaan edistyneimpään kokeiluun.

Lisäksi analysoimme erityisesti oppilaitoksen kouluttajan, pseudonyymiltään Vienon, kehittämistoimijuuteen liittyviä puheita ja tekoja. Valitsimme Vienon näkökulman, koska hän erottui aineistosta aktiivisimpana kokeilun toimeenpanijana. Lisäksi hänellä oli ammattiroolinsa ja asemansa vuoksi mahdollisuus siirtää yhteistyökäytäntöä jatkossa uusiin työpaikkasuhteisiin. Vieno osallistui pajojen suunnitteluun fasilitoijien ja HR-edustajan kanssa. Koska analyysi keskittyi osin yksilötasolle, hyvän tutkimuskäytännön mukaisesti Vieno sai artikkelikäsikirjoituksen eri versiot luettavakseen ja antoi luvan käsikirjoituksen julkaisemiseen.

Luokittelimme pajojen 2 ja 3 analyysiin valittujen keskustelujen litteraatiot käyttäen apuna kehittämistoimijuustekojen (taulukko 1) pohjautuvaa analyysitaulukkoa. Sen ensimmäiseen sarakkeeseen nimesimme kollektiivisen kehittämistoimijuusteon ja toiseen sarakkeeseen sen, miten Vienon puheteot ja toimijuus ilmenivät. Kolmannessa sarakkeessa tiivistimme, mitä itse puheen kohteelle tapahtui.

Lisäksi haimme pajojen 2 ja 3 ryhmäkeskustelusta lingvistisiä johtolankoja (Engeström \& Sannino $2011,374)$ toimijuudesta. Tunnistimme sekä yksilöiden aloitteita puhujittain (mä, minä) että yhdessä ehdotettua kehittämistoimijuutta (me). Minä-, mäja me-sanat haettiin Word-tekstinkäsittelyohjelman etsi-toiminnolla, ja niiden esiintymisestä tehtiin frekvenssianalyysi puhujittain.

Muutospajojen 1 ja 4 sisällöstä muodostimme tapahtumien kulkua kuvaava narratiivin litteraatioista tulkitsemalla. Lisäksi liitimme muutospajojen 2 ja 3 tarkemman analyysin yhteisistä kehittämisteoista osaksi muutospajaprosessin kehityskuvausta. Esi- 


\section{VIENOA VOI KUVAILLA}

\section{TAUSTALTAAN}

\section{YRITYSMAAILMASTA}

\section{OPPILAITOKSEEN SIIRTYNEEKSI}

\section{RAJANYLITT $\ddot{A}$ ÄKSI.}

merkkiotteita otimme erityisesti keskustelua suuntaavasta jännitteisimmästä teosta 3, jossa osallistujat kritisoivat nykyistä toimintaa ja ilmaisevat muutostarvetta.

Analyysin ensimmäisestä vaiheesta vastasi ensimmäinen kirjoittaja. Toinen ja kolmas kirjoittaja tarkistivat kaikki analyysit, minkä jälkeen keskustelimme niiden tulkinnasta, kunnes olimme yksimielisiä. Koska olimme kiinnostuneita kokeilun kestävyydestä ja kouluttajan toimijuudesta sen edistäjänä, tavoittelemme raportoinnissa etnografista ja sensitiivistä tapahtumien kulun yksityiskohtaista kuvaamista. Siten ymmärrys kehityksestä kontekstissaan avautuu lukijalle vaihe vaiheelta (ks. Hasu 2005).

\section{MUUTOSPAJAPROSESSISSA KEHITTYNYT KAUPAN JA OPPILAITOKSEN YHTEISTYÖ}

Avaamme Vienon näkökulmasta muutospajaan osallistumisen lähtökohdan ja kunkin muutospajan etenemisen. Kuvaamme, miten Vieno vei muutospajassa kehitettyä yhteistyökäytäntöä eteenpäin ja miten hän reflektoi pajaprosessia jälkikäteen.

\section{Kouluttaja Vienon toimijuus on suuntautunut yritysyhteistyön parantamiseen}

Vienolla oli urakokemusta vähittäiskaupan johtotehtävistä ja viideltä viime vuodelta yrittäjien ja ammattijohtajien kouluttajana. Häntä voi kuvailla taustaltaan yritysmaailmasta oppilaitokseen siirtyneeksi rajanylittäjäksi. Hän tunsi omakohtaisesti työpaikkojen ja oppilaitoksen yhteistyön vaikeuden ja etsi jo ennakkohaastattelussa ratkaisuja yhteistyön edistämiseksi. Ammatillisen koulutuksen uudistus oli vienyt enem- män vastuuta oppimisesta työpaikkakouluttajille, mutta sekä haastattelupuheessa että ennakkotehtävässä Vieno korosti kauppojen kiristyvän kilpailutilanteen ja kiireen estävän yhteistyötä oppilaitosten ja kauppojen välillä. Hän tunnisti kauppiaiden ajanpuutteen toimia työpaikkakouluttajina ja toivoi, että ajatus opiskelijan ohjaamisesta voitaisiin työpaikoilla nähdä mahdollisuutena muutokseen:

"Ett jos se sinne yritysmaailmaan saataisiin ujutettua tää idea, niin sehän pitäis heillä nähdä myös mahdollisuutena. Ett siellä ois kauppiailla, tietsä, mahollisuus, et hei, nyt mä koulutan täst porukasta. [--] ett teillä on mahdollisuus kehittää koko teidän yritystoimintaa tän kautta." (ennakkohaastattelu 21.8.2018)

Haastatteluotteessa näkyy ajatus siitä, että koulutusohjelmaan osallistuvan valmennettavan kanssa koko yritystoimintaa voisi uudistaa. Tämä kuvastaa juuri uudenlaista tapaa nähdä opiskelija ja oppiminen ei vain olemassa olevien käytäntöjen omaksujana vaan niiden uudistajana (kuten Gherardi, Nicolini \& Odella 1998).

\section{Paja 1: Työn muutos ja osaamistarpeet}

Vieno ei päässyt osallistumaan ensimmäiseen muutospajaan. Osallistujien esittäydyttyä fasilitoijat antoivat ennakkokyselystä kootun tiivistyksen, johon oli koottu osallistujien näkemyksiä kaupan alan muutoksesta. Oppimisen välineenä käytettiin nelikentästä muodostettua kehityskarttaa (kuva 2; Ahonen, Virolainen \& Gardemaister 2020).

Osallistujat jaettiin tehtävärooleittain kolmeen sekaryhmään, ja tehtäväksi annettiin pohtia nykytyötä ja tulevaa: Mitä jo hallitaan hyvin? Mitä uusia työntekemisen tapoja olette kehittämässä, jotka enteilevät jo tulevaisuutta? Yksi ryhmä pohti muutosta asiakkaiden, toinen liiketoiminnan ja kolmas sisäisten toimintatapojen näkökulmasta. Tämän jälkeen pohdittiin, millaista osaamista nykyisen toiminnan sujuvuus edellytti ja millaista uutta osaamista kaupat tarvitsisivat.

Ryhmätyökeskustelut sisälsivät paljon nykyisen toiminnan kritisointia ja muutostarpeen kuvailua 
(teko 3). Esimerkiksi toimintatapojen muutosta pohtinut ryhmä keskusteli kaupan kanavien muuttumisesta ja henkilöstön vaihtuvuudesta epäkohtina. Kehityskartta ohjasi osallistujat jäsentämään tulevaa, jolla selitettiin toiminnan uusia mahdollisuuksia (teko 4), kuten liiketoiminnan muutosta käsitellyt ryhmä kiteytti:

"Ammatillinen osaaminen nimenomaan tuotetiedon näkökulmasta on kohdallaan, ja meil on välineet, joilla sitä kasvatetaan. Sitten konseptit osataan ja kaupan perusjärjestelmien peruskäyttö hallitaan. No sitten niitä uusia, nyt ituina olemassa olevia asioita on ensinnäkin ratkaisumyynti sekä xx että zz-kaupassa niin laajempien kokonaisuuksien myynti. Ja parhaat osaa sen jo." (liiketoimintaryhmän puheenvuoro, paja 1)

Kokonaisuudessaan kahden virikkeen menetelmä, toisin sanoen ennakkotehtäväaineisto ja kehityskartta, ohjasi osallistujat muodostamaan yhteisen käsityksen kaupan muutoksen suunnasta.
Ryhmien välisessä keskustelussa nykyinen toimintamalli sai nimen "tuotteita asiakkaalle" ja tuleva nimen "ratkaisuja asiakkaalle". Yhdessä rakennetusta kehityskartan ilmiasusta tuli väline ja hahmotus vähittäiskaupan alan lähikehityksestä, jota fasilitoijat käyttivät lähtökohtana seuraavissa pajoissa.

\section{Paja 2: Nykyiset yhteistyökäytännöt}

Pajan 2 pääteemana oli kartoittaa nykyisiä oppilaitostyöpaikkayhteistyön käytäntöjä ja arvioida yhdessä, miten ne vastaavat uudistuviin oppimistarpeisiin. Oppimisen välineinä olivat kehityskartta ja aikajana, johon oli kuvattu rinnakkain yrittäjän ammattitutkinnon opetussuunnitelma ja nykyiset yhteistyökäytännöt. Vieno muodosti kahden muun kouluttajan kanssa yhden ryhmän. Hän arvosteli heti keskustelun alussa yhteistyön toimimattomuutta ja kauppiaiden aikapulaa työpaikalla tapahtuvaan ohjaukseen (teko 3). Hän suuntasi keskustelua löytämään juuri tähän ratkaisua.

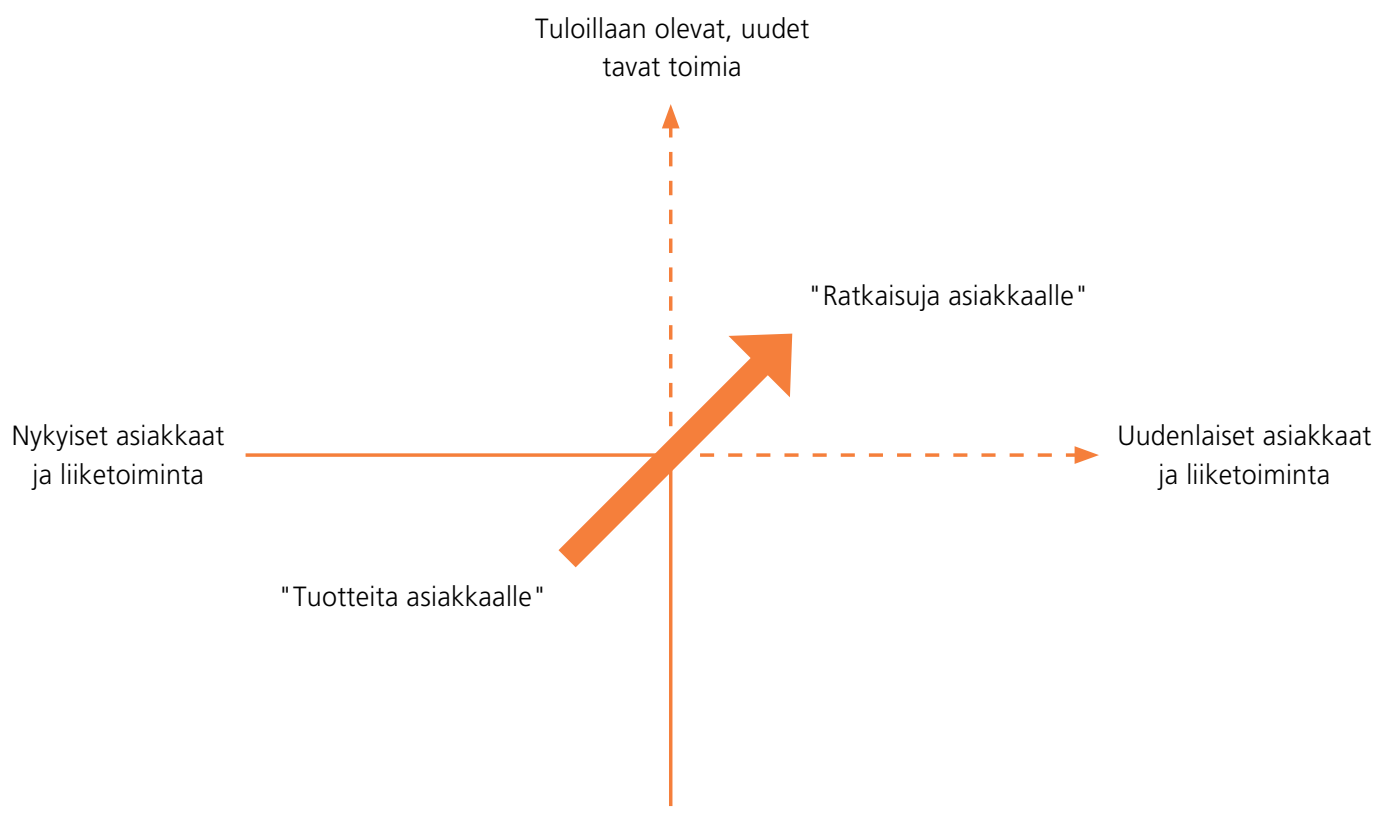

Nykyiset tavat toimia

Kuva 2. Kehityskartta. 
"Varmasti tässä alussa on se ensimmäinen kriittinen paikka eli sinne vaan pitäisi kylmästi vaan ottaa se kauppias mukaan siihen keskusteluun. Se aika pitää ottaa siihen, että sillä kauppiaalla on se aika lähteä siihen keskusteluun. Ja musta [kouluttaja B:Ilä] oli erittäin hyvä se sun kommentti siellä, että jatkossa se ohjaaminen, että siihen pitäisi saada se porkkana sille kauppiaalle, että se kokisi, että hän hyötyy siitä jotakin. Ettei se koe sitä rasitteena. Että nyt mulla menee aikaa tähänkin hommaan ihan helkatisti. Että se on toinen juttu. Mutta sanoisin, että kaksi kriittistä kohtaa on, tämä aloitus ja tässä matkan varrella tapahtuva yhteistyö."

Vieno toimi keskustelun pääasiallisena vetäjänä. Alusta alkaen hän asemoi itsensä asemoi uuden yhteistyökäytännön tekijäksi. Se toteutettaisiin kouluttajan, kasvattajakauppiaan ja opiskelijan välisenä videopuheluna. (teko 1).

"Mutta todellakin tämä yhteistyön tekeminen on, että tähän pitää löytää nyt se viisastenkivi, millä tavalla, siis varmaan minä, pitää peiliin katsoa, että miten minä saan ne kauppiaat tähän aloitukseen mukaan."

Vieno ilmaisi aikomuksenaan ottaa yhteyttä kasvattajakauppiaisiin (teko 5), tehdä henkilökohtaisesti toteutetun testin nähdäkseen, onnistuisiko oppilaitoksen ja kaupan välinen yhteistyökäytäntö. Hän luonnehti videopuhelusovelluksella toteutettavan yhteistyön sisältöä:

”Ja käyn vähän sitä koko valmennusta läpi, että mitä se pitää sisällään ja keskustelen siitä hänen [kasvattajakauppiaan] roolistaan, siitä just niin kuin tukemisnäkökulmassa”.
Lisäksi Vieno sitoutti uudenlaisen käytännön tekemiseen itsensä (teko 6) ja puhui ikään kuin itselleen tulevien tekojensa vahvistukseksi.

"Elikkä tämä olisi nyt tähän alkuhommaan, että mä teen ja mä teen sen. Minä teen sen. Mulla on nyt hyvä aloitus, koska mä voin sanoa, että mä käytännössä tämän teen ensi viikolla.”

Otteessa huomio kiinnittyy sen toisteiseen ja painokkaaseen tapaan nimetä "mä" tai "minä" aloitteen tekijäksi. Nauhalta kuunneltuna Vienon puhe oli tunnesävyltään innostunutta ja tempoltaan nopeaa. Muut kouluttajat tukivat Vienon toimijuutta ja rikastivat kehittelyn alla olevaa yhteistyökäytäntöä, mutta eivät tuoneet esiin omaa toimijuuttaan tai tulevia tekojaan. Havaintoa tukee analyysi ryhmäkeskustelussa käytettyjen mä-, minä- ja me-ilmaisujen määrästä. Vienon puheessa esiintyi eniten minä- ja mä-ilmaisuja verrattuna muihin ryhmän jäseniin (taulukko 4).

Ryhmäkeskustelun loppupuolella Vienon energinen puhe muuttui vaisummaksi. Hän ei hakenut tukea toisista kouluttajista vaan ideoi, että kaupan johtotaso voisi tulla hänen avukseen yhteistyökäytännön käynnistämiseen. Näin hän laajensi kehittämistoimijuutta kaupan johtoon (teko 1), vaikka ryhmässä ei vielä ollut ketään ottamassa toimijuutta vastaan.

Vaikka Vieno oli ollut ryhmän kantava voima ja keskustelua vetänyt osallistuja, hän ei halunnut esittää ryhmätyön tuloksia. Kun uusi käytäntö oli esitelty yleisellä tasolla, Vieno huudahti koko pajayleisölle:

”Hei vielä, mulla on alkamassa nyt x-kauppiasvalmennus tässä kuukauden kuluttua. Ja ajattelin nyt tehdä tämmösen pienimuotoisen testin, elikä mä laitan ensi viikolla näille opiskelijakauppiaille viestin ja ehdotan tämmöstä Skype-palaveria."

\begin{tabular}{|c|c|c|c|}
\hline Ilmaisu & Vieno & kouluttaja B & $\begin{array}{l}\text { terveydenhuollon } \\
\text { kouluttaja }\end{array}$ \\
\hline Mä tai minä & 47 & 21 & 1 \\
\hline $\mathrm{Me}$ & 8 & 5 & 7 \\
\hline Yhteensä & 55 & 26 & 8 \\
\hline
\end{tabular}

Taulukko 4. Minä-, mä- ja me-ilmaisujen määrä Vienon kouluttajaryhmässä pajassa 2. 
Hän ilmaisi sitoutumista kehittämistekoihin kertoessaan tulevasta toiminnastaan julkisesti. Aikomuksellaan hän samalla meni suunnitellun interventioprosessin edelle, lupasi tehdä kokeilun aloitteen, testin seuraavalla viikolla.

\section{Paja 3: Kohti uudenlaista yhteistyötä}

Pajan 3 tavoite oli tuottaa tulevia yhteistyön tapoja. Fasilitoija kärjisti pajan alussa jännitettä kahden vaihtoehdon välillä: Missä määrin yhteistyö sujuvoittaisi nykyistä sujuvaa koulutuspolkua eli vahvistaisi vanhaa totuttua toimintatapaa? Missä määrin se taas voisi rakentaa jo uudistuvaa toimintatapaa siten, että opiskelijat olisivat mukana tuottamassa kaupan ratkaisuja asiakkaalle -mukaista tulevan työn toimintatapaa? Työpajan tarkoitus oli suunnitella uudenlaisen yhteistyökäytännön sisältö ja sitä edustava kokeilu, jota osallistujat kokeilisivat ennen viimeistä muutospajaa noin neljän kuukauden ajan. Kokeilun suunnitteluun ja konkretisointiin tarjottiin kysymyspohja.

Vieno osallistui ryhmään, jossa oli kauppias, valmennettava ja kaupan ylemmän johdon edustaja, aluepäällikkö. Hän reagoi ryhmäkeskustelussa nopeasti heti keskustelun alussa fasilitoijien pyyntöön ideoida uusia yhteistyön tapoja, mutta ennakoi ettei työpaikkaosallistujilla olisi tarpeeksi aikaa tehdä yhteistyötä:

"Kauppojen ja oppilaitoksen x välistä yhteistyötä. No, minä tiedän kohteen, mutta en tiedä, kuinka se käytännössä toteutetaan. Tehän voitte antaa mulle vinkkejä. Itse koen omasta näkökulmastani, ett se säännöllinen yhteydenotto esimerkiksi kauppiaan kannalta, miten se on ajallisesti [kannattaa ajoittaa]. Mä tiedän, kun kohta tulee toukokuu, niin kukaan kauppa ei haluu mun kanssa keskustella. Että mä haluaisin jutella sun [kauppiaan] kans opinnoista. Te sanotte, juokse jokeen, eikö."

Otteessa Vieno ilmaisee olevansa tietoinen työpaikkojen kiireistä ja vähäisestä kiinnostuksesta oppilaitosyhteistyöhön. Puhe oli sarkastista, ja siinä oli provosoiva sävy. Vieno ikään kuin ennakoi sanat kauppiaan ja johdon edustajan suuhun ja samalla toi ratkaistavan ongelman yhteiseksi keskusteluaiheeksi: "tehän voitte antaa vinkkejä". Ote voidaan tulkita yhtäältä yhteistyön nykytilan arvosteluksi: "te sanotte juokse jokeen, eikö?" ja toisaalta aloitteeksi ja avunpyynnöksi nostaa muutoksen tarve yhteiseen keskusteluun (teko 3). Vieno kertoi muille henkilökohtaisen kokeilunsa tuloksista pettyneeseen sävyyn. Yhteistyöpyyntö kasvattajakauppiaille ei ollut saanut varauksetonta vastakaikua.

"Mä laitoin yhdelletoista viestin nyt alkaneelle [kasvattajakauppiaalle] ja niistä kolme laitto mulle, että pidetään tämmönen Skype. Oliks se nytten neljä ilmotti, että en tarvitse mitään selventävää materiaalia. Ja loput ei ilmoittanu mitään tai kommentoi jotain."

Vienon tiedonanto tekemästään teosta edusti tekemistä ja toimimista työn muuttamiseksi (teko 7). Kun hän kertoi edellisessä muutospajassa syntyneestä ideasta ottaa kasvattajakauppiaat mukaan osittain myös koulutusjaksojen alkuun, tästä kehittyi keskustelu, jossa pohdittiin, milloin kukin kauppias voisi jaksoille ajankohdallisesti osallistua. Aluepäällikkö ilmaisi halunsa osallistua joillekin koulutusjaksoille ja osoitti siten sitoutumista toimintaa muuttaviin tekoihin (teko 6). Vieno kutsui aluepäällikköä tuekseen miettimään aloituskokousten sisältöä:

"Oikeasti herra x, kuule mietitään se sisältökin, ettei se vaan [jää sille tasolle, että] mä kun nyt soitan, pannaan Skype-palaveri pystyyn, että jutellaan mukavia tässä näin.”

Tästä seurasi keskustelu, jossa he sopivat suunnittelupalaverin. Nykyisen työn oppimisen ja työn muutokseen liitettyjen osaamistarpeiden välinen jännite pilkahti keskustelun loppupuolella (teko 3). Opiskelija kertoi kokeneensa, ettei kasvattajakauppiaan kanssa päästy kehittämään uutta, vaan toistettiin vanhaa:

"Mä muistan tehneeni riskienhallinnan kehittämisen. Ja me oltiin tehty se ehkä niin kun vuosi sitten, että vaan sit kirjotin puhtaaks. Mehän ei keksitty siinä mitään uutta, koska sehän ois pitänyt sitten taas miettiä, ett se ei ollut kaupan etu."

Ote heijastaa opiskelijan joutuneen asemaan, jossa hänelle jäi varsin kapea-alainen puhtaaksikirjoittajan rooli, eikä yhdessä kehittäminen ollut toteutunut. 


\begin{tabular}{|l|l|l|l|l|l|}
\hline \multicolumn{2}{|c|}{ IImaisu } & opiskelija & aluepäällikkö & $\begin{array}{l}\text { kauppias- } \\
\text { yrittäjä }\end{array}$ & fasilitoijat \\
\hline Mä tai minä & 51 & 24 & 39 & 46 & 27 \\
\hline Me & 38 & 7 & 35 & 13 & 23 \\
\hline Yhteensä & 89 & 31 & 74 & 59 & 50 \\
\hline
\end{tabular}

Taulukko 6. Minä, mä ja me ilmaisujen määrä Vienon sekaryhmässä pajassa 3.

Kauppiasosallistuja puolestaan tuskaili, kuinka vaikeaa tulevan toimintatavan opettaminen käytännössä olisi (teko 3).

"Tos oikees pallossa [ratkaisuja asiakkaalle, kehityskartan kohta] on aina just se ongelma, ett kun kauppiaat ei itekään osaa tota, ett niin millä koulutat sen sitten. Ett siis, koska sillä tulee olemaan meille ihan hirveä tuska saada toi ratkaisuja asiakkaalle opittua oikeesti."

Otteessa ilmenevät olemassa olevan toiminnan ja tulevaisuuden haasteiden välinen jännite ja eräänlainen hämmennys siitä, kuinka opettaa opiskelijoille sellaista, mitä ei vielä ole olemassa. Oppiminen miellettiin perinteisenä mestari-kisällimallina.

Aluepäällikkö oivalsi keskustelussa, että valmennettavat voisivat tuoda juuri kaivattua uutta näkemystä koulutukseen osallistumisen kautta kaupan tekemiseen:

"Se ois ihan niin kun kaupan tekemistä. Ja sehän nivoutuis silloin, syntyiskin molempien etu. Se valmennettava tois siihen kauppaan sitä uutta ajatusta ja sit se vanha kauppias tois sen vanhan pölyttyneen rutiinin.”

Ote ilmaisee opiskelijan ja työpaikkaohjaajan oppivan tasavertaisena yhdessä. Opiskelija miellettiin mahdollisuutena saada työhön aineksia, joilla voitiin vastata tulevaisuuden haasteisiin. Oppiminen nähtiin siis yhdessä kehittelynä, ei tiedon siirtämisenä työpaikalta opiskelijalle.

Keskustelun kuluessa itse kokeilun kohde laajeni rutiineista kohti tulevia uusia työkäytäntöjä. Samalla Vieno sai kauppiaan ja aluepäällikön innostumaan koulutusjaksoille osallistumisesta. Keskustelussa muotoutui aloituskokouksen alustava agenda: kerrotaan koulutusjaksosta, annetaan tehtävä opiskelijalle, ja opiskelija kertoo, mitä aikoo tehdä harjoittelujaksolla. Vieno sai houkuteltua kehittämistekoihin aluepäällikköä työparikseen.

Pajaan 2 verrattuna kehittämistoimijuus ilmeni pajassa 3 enemmän yhdessä tapahtuvana muutostarpeesta keskusteluna. Myös uutta yhteistyökäytäntöä kehiteltiin yhdessä. Vienon puheessa esiintyi silti eniten mä- tai minä-sanoja, mikä ilmaisee hänen toimineen keskustelussa kokeilun aloitteen tekijänä. Me-sanojen käyttö oli yleisintä Vienon ja aluepäällikön puheessa, mikä vahvisti sitä havaintoa, että he muodostivat kokeilun toimeenpanijatyöparin.

\section{Yhteenveto pajoissa 2 ja 3 ilmenneestä kehittämistoimijuudesta}

Ryhmien keskusteluissa tunnistettujen kehittämistekojen määrät kuvataan käyttäen analyysiyksikkönä episodia, eli niiden puheenvuorojen jonoa, joissa puhutaan samasta aiheesta (taulukko 5).

Nykyisen toiminnan kritisointi ja muutostarve (3) vaikutti olevan vaihe, josta ei päästy eroon siirryttäessä kohti uuden yhteistyökäytännön kehittämistä (paja 3) vaan johon palattiin uudelleen eri osallistujien näkökulmista. Oman toimijuuden asemointi suhteessa toisiin (teko 1), esiintyi erityisesti Vienon puheena. Hänelle oli tärkeää asemoida ikään kuin julkisesti oma roolinsa suhteessa kehittämistekoihin. Suhteellisen paljon esiintyi myös sitoutumista toimintaa muuttaviin tekoihin (teko 6), mikä viittasi yhteiseen sopimiseen siitä, miten kokeilua viedään eteenpäin. 


\section{Paja 4: Kokeilujen arviointi}

Pajan 4 tarkoitus oli arvioida toteutettuja kokeiluita. Vieno oli toiminut työn muuttamiseksi (teko 7):

"Skypen avulla kontaktoidaan kauppoja. Otetaan mukaan kauppias ja aluepäällikkö. Se tuo mukaan selkärankaa, että saadaan kiireiset kauppiaat ottamaan aikaa tälle valmennukselle. Mulla on meneillään nyt x-kauppavalmennus, 11 opiskelijalle. Lähdin sitten heitä kontaktoimaan. Olin sopinut aluepäällikön kanssa, että miten hänen aikatauluunsa tällainen palaveri istuu. Sit olin yhteydessä sinne kauppiaaseen, että löytyskö aikaa. No löytyi ja sit opiskelijaan. Pidettiin palaveri, jossa oli aluepäällikkö, kauppias, opiskelija ja minä. Meillä oli oikeinkin hyvät palaverit."

Vieno kuvaili viittä toteutunutta videopalaveria onnistuneiksi. Yllättävä muutos työpaikalla, aluepäällikön vaihtuminen, oli kuitenkin tilapäisesti pysäyttänyt hyvin käyntiin lähteneen yhteistyökäytännön. Vieno kertoi aikovansa pitää videopalaverit kolme kertaa koulutuksen kuluessa ja jatkavansa kesken jääneitä kauppiaiden kontaktointeja keväällä.

Muutospajassa Vieno työskenteli ryhmässä, jossa oli hänen lisäkseen kaksi HR-toimijaa. He kannustivat Vienoa jatkamaan käytäntöä edelleen. Arviointikeskustelussa hän tunnisti kokeilun esteiksi vaikeudet löytää yhteisiä aikoja kauppiaiden ja aluepäällikön kalentereista sekä välillä tietotekniset haasteet.
HR-toimijat puolestaan ehdottivat käytännön laajentamista muihin koulutuksiin, mikä edusti yritystä uuden käytännön vakiinnuttamiseen (teko 8).

\section{Vienon toimijuus ja teot muutospajan jälkeen}

Vuoden kuluttua muutospajan päättymisestä Vieno kertoi, että oppilaitoksen ja työpaikan välinen yhteistyö oli ollut hänelle "jo vuosia takaraivossa vähän ahdistava tekijä." Hän oli vienyt syksyllä viimeiset palaverit läpi kauppiaiden, aluepäällikön ja opiskelijoiden kanssa (teko 8). Vienosta oli kehittynyt palavereissa kauppiaan ja opiskelijan välille keskinäistä yhteistyötä parantava fasilitoija, ja hän tiedosti, ettei mahdollisia epäkohtia työssä oppimisesta ollut helppo käsitellä.

"Ensin katsottiin ne menneet ja sit katsottiin, että mitä on vielä siellä tulemassa. Sit mä nimenomaan kysyin opiskelijalta, että hän kertoisi sitä työssä tapahtunutta oppimista. Sen mä huomasin, että se oli vähän arka asia. Kyl mä ymmärrän, että jos ei se välttämättä ollu sujunu kaupassa hyvin, niin opiskelija oli aika nolossa tilanteessa, että hän siinä kauppiaan kuullen sanoo, että 'ei täällä oikein oo tapahtunu mitään'. Mun täytyi sitä aina jotenkin lieventää, että en enää voinu niin jyrkillä sanoilla kysyä sitä."

Vieno kertoi yrittäneensä jatkaa käytäntöä muissa koulutuksissa, mutta edelleen yhteisen ajan löytyminen oli haasteellisinta kokeilun jatkuvuudelle:

\begin{tabular}{|c|c|c|}
\hline Kehittämistoimijuuden ilmaukset & $\begin{array}{l}\text { Paja 2, } \\
\text { kouluttajaryhmä }\end{array}$ & $\begin{array}{l}\text { Paja 3, } \\
\text { sekaryhmä }\end{array}$ \\
\hline 1 Oman toimijuuden asemointi ja merkitys & 3 & 2 \\
\hline 2 Johdon ja kehittäjien vastustaminen & 0 & 0 \\
\hline 3 Nykyisen toiminnan kritisointi ja muutostarve & 3 & 6 \\
\hline 4 Toiminnan uusien mahdollisuuksien selittäminen & 2 & 3 \\
\hline $\begin{array}{l}5 \text { Toiminnan uusien toimintatapojen tai -mallien visualisointi ja } \\
\text { suunnittelu }\end{array}$ & 5 & 6 \\
\hline 6 Sitoutuminen toimintaa muuttaviin tekoihin & 3 & 5 \\
\hline 7 Tekeminen ja toimiminen työn muuttamiseksi & 0 & 1 \\
\hline 8 Uuden käytännön vakiintuminen intervention jälkeen & 0 & 0 \\
\hline
\end{tabular}

Taulukko 5. Muutospajoista 2-3 tunnistetut kehittämistoimijuutta edustavien episodien määrä. 
"Mä sain ehkä innostuksen jatkaa tätä muilla valmennuksilla. Olen jopa yrittänytkin ottaa sitä, mutta edelleen haasteena tuntuu olevan tänä päivänä se ajan löytäminen. Ei siis minun ajan, vaan niitten työpaikkakouluttajien. [--] Mä luulen, ett se on se aika. Tää on aika tylsää sanoo, jatkuvasti toitottaa tätä samaa asiaa, mut se vaan tuntuu olevan, että kaikilla on niin kiire. Tuntuu, että tää on se viimeinen, mistä se aika ensimmäisenä tipautetaan pois."

Yhteistyökäytäntöjen kokeilu yritysten aloitteesta jäi toteutumatta, ja muutospajan päätyttyä HR-toimijat esittivät huolensa kokeilun kaltaisen yhteistyökäytännön hiipumisesta.

\section{JOHTOPÄÄTÖKSET}

Kokonaisuudessaan analyysimme osoittaa, että muutospaja sai aikaan oppilaitoksen ja työelämän välisen yhteistyökäytäntökokeilun, jonka kehittelyssä ja toimeenpanossa sekä vakiinnuttamisessa kouluttaja Vienon kehittämisteot olivat ratkaisevia. Muutospajassa ilmennyttä osallistujien yhdessä tuottamaa kehittämistoimijuutta kuvasimme ekspansiivisen oppimisen vaiheita mukailevalla kehittämistekojen luokittelulla. Narratiivinen tapahtumien kuvailu toi esiin sen, miten yksilöllinen toimijuus vei kokeilun muodon kehittymistä eteenpäin mutta myös, kuinka hauraasti kokeilun juurtuu pysyväksi käytännöksi, jos se jää vain yhden toimijan aktiivisuuden varaan.

Kouluttaja Vienon yksilölliset aloitteet ja osallistuminen muutospajaprosessin suunnittelun tasolla, pajojen vuorovaikutuksessa sekä pajojen ulkopuolisessa verkostossa veivät yhteistyökäytäntöä kokeilusta käytäntöön (kuva 3).

Vienon toimijuutta ja aloitteellisuutta vahvisti todennäköisesti osallistuminen pajojen suunnitteluun.

\begin{tabular}{|c|c|c|c|c|}
\hline $\begin{array}{l}\text { Yhteistyö } \\
\text { verkostossa }\end{array}$ & & $\begin{array}{l}\text { Vienon viesti uudesta } \\
\text { yhteistyökäytännöstä } \\
11 \text { kasvattaja- } \\
\text { kauppiaalle: } \\
3 \text { myönteistä ja } 4 \\
\text { kielteistä vastausta, } \\
4 \text { ei vastannut }\end{array}$ & $\begin{array}{l}\text { Vieno piti } 5 \\
\text { video-palaveria } \\
\text { opiskelijoiden } \\
\text { ja kasvattaja- } \\
\text { kauppiaiden kanssa. } \\
\text { Aluepäällikön } \\
\text { vaihtuessa käytäntö } \\
\text { pysähtyi. }\end{array}$ & \\
\hline \multirow[t]{2}{*}{ Muutospaja } & Paja 1 & Paja 2 & Paja 3 & Paja 4 \\
\hline & $\begin{array}{l}\text { Kehityskartta tuottaa } \\
\text { yhteisen suunnan } \\
\text { kehittämiselle } \\
\text { (Vieno poissa) }\end{array}$ & $\begin{array}{l}\text { Kouluttajaryhmä: } \\
\text { Vieno esittää idean } \\
\text { työpaikoille soitosta }\end{array}$ & $\begin{array}{l}\text { Verkostoryhmä: } \\
\text { Vieno kertoo } \\
\text { testistään, Vieno } \\
\text { ja aluepäällikkö } \\
\text { sopivat palaverin } \\
\text { ja tekevät agendan } \\
\text { yhteistyöpalaverille. }\end{array}$ & $\begin{array}{l}\text { Vieno kertoo } \\
\text { aikeensa jatkaa } \\
\text { yhteistyöpalavereja, } \\
\text { kiire ja tietotekniset } \\
\text { välineet esteinä. HR } \\
\text { kannustaa. }\end{array}$ \\
\hline & & $\nabla$ & $\downarrow$ & $\downarrow$ \\
\hline \multirow[t]{2}{*}{$\begin{array}{l}\text { Intervention } \\
\text { suunnittelu } \\
\text { ja tutkimus }\end{array}$} & \multicolumn{3}{|c|}{$\begin{array}{l}\text { Suunnittelupalaveri ennen jokaista muutospajaa (Fasilitaattori, Vieno } \\
\text { ja HR) }\end{array}$} & $\begin{array}{l}\text { Analyysi Vienon } \\
\text { toimijuudesta } \\
\text { muutos-pajoissa } \\
\text { ja Vienon antama } \\
\text { julkaisulupa } \\
\text { 3-5/2020 }\end{array}$ \\
\hline & \multicolumn{3}{|c|}{ 8/2018: Vieno tunnistaa työelämäyhteistyön haasteet } & $\begin{array}{l}\text { Jälkihaastattelu: } \\
\text { Vieno kertoo } \\
\text { jatkavansa kehitettyä } \\
\text { käytäntöä muissa } \\
\text { koulutuksissa, } \\
\text { mutta ennakoi } \\
\text { työpaikkojen kiireen } \\
\text { estävän käytännön } \\
\text { vakiintumista }\end{array}$ \\
\hline
\end{tabular}

Kuva 3. Muutospajaprosessi ja sen seuraamukset Vienon kehittämistoimijuuden näkökulmasta. 
Koska Vieno tiesi etukäteen pajan käsikirjoituksen, hänellä oli valmius aloittaa keskustelu ensimmäisenä ja siten määrittää sisältöä vahvemmin kuin muilla osallistujilla. Hänen vahvaa motivaatiotaan saattaa selittää myös rajanylitys uralla: Vieno oli siirtynyt kaupan kentältä oppilaitoksen kouluttajaksi.

Varsinkin pajan 3 keskusteluissa pääsivät esiin myös muiden osallistujien kokemukset työelämäyhteistyöstä ja siinä vallitsevista jännitteistä. ”Yhdessä oppimisen ja vähittäiskaupan lähikehityksen vyöhykkeellä” voidaan nähdä jokaisen roolin puhetavan ilmentäneen omanlaistaan toiminnan jännitettä

\section{(kuva 4).}

Kasvattajakauppias suhtautui myönteisesti oppilaitosyhteistyöhön, mutta oli kiinni nykyisen liiketoiminnan rutiineissa. Opiskelijan ääni kuului keskustelussa heikompana kuin muiden, ja hänen murtautumisensa kehittämään kokonaan uutta vaatisi vahvempaa tukea. Johto näki oppilaitosyhteistyön mahdollisuutena liiketoiminnan uudistamiseen, mutta kiire ja johtajavaihdos katkaisivat yhteistyön.
Kouluttaja toimi ponnekkaasti yhteistyön organisoijana ja siirsi käytäntöä uusiin työpaikkoihin, mutta jäi yksin kantamaan huolta yhteistyökäytännön vakiintumisesta. Analyysimme jättää katveeseen sen, miten muutospaja vaikutti työpaikkaosallistujien ajattelu- ja toimintatapoihin tulevaisuudessa, kuten kehittämisideoihin paremmasta oppilaitosyhteistyöstä.

Aiempien tutkimusten (Jokinen, Lähteenmäki \& Nokelainen 2009) löydös työelämäyhteistyön jäämisestä oppilaitosten opettajien vastuulle saa tutkimuksestamme vahvistusta. Toistuvana käytännön leviämistä estävänä tekijänä tulivat esiin työpaikan kiire ja kiireen kunnioittaminen. Ne menivät arvoasteikossa poikkeuksetta yhteistyökäytännön toteuttamisen edelle. Tämä havainto voi yhtäältä liittyä työelämän tahdin tiivistymiseen muun muassa digitalisaation myötä (Mauno, Minkkinen \& Auvinen 2019). Toisaalta se voi olla sidoksissa opettajien yksilökeskeiseen ammatilliseen työkulttuuriin, joka ilmenee yksin pärjäämisen eetoksena ja autonomisuuden kunnioittamisena (Laajala 2016).

Tuloillaan olevat, uudet tavat toimia

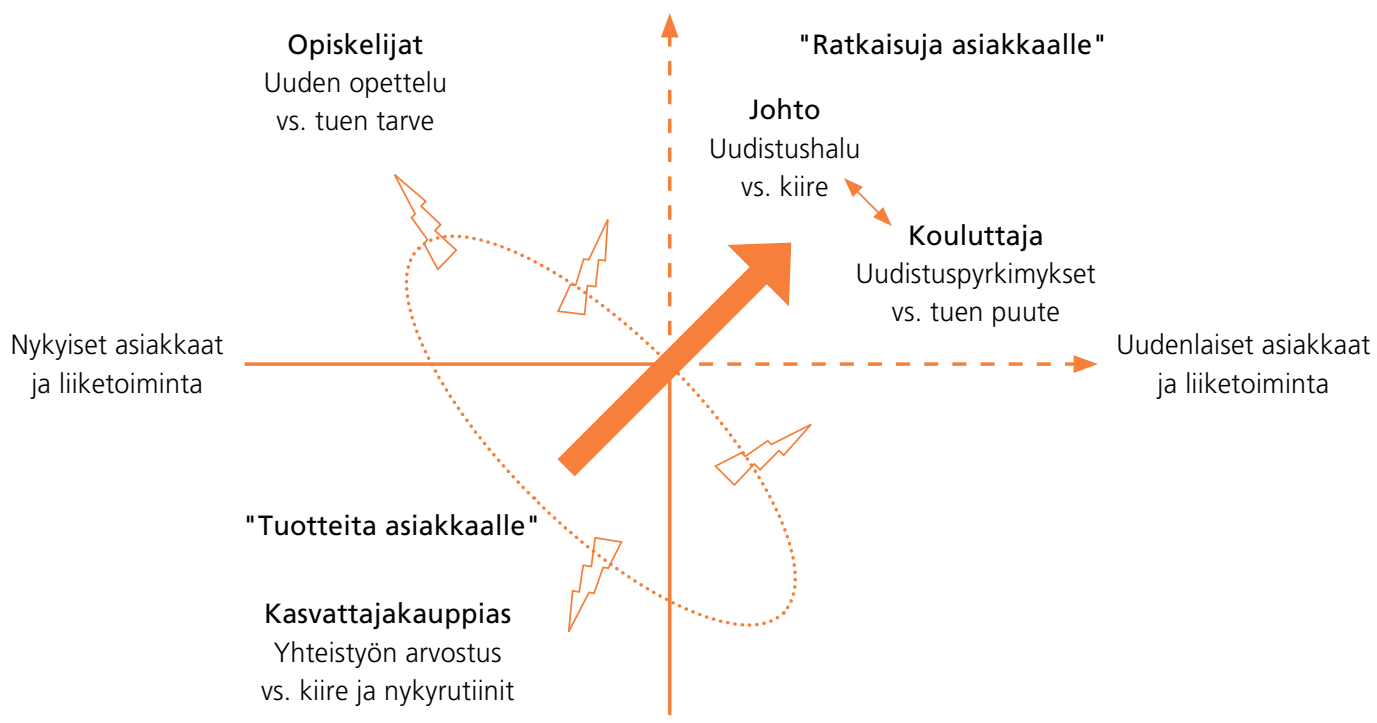

Nykyiset tavat toimia

Kuva 4. Muutospajan toimijoiden jännitteet ja lähikehitys. 


\section{POHDINTA}

Interventio vahvisti niin yksilöllistä kuin yhteistä kehittämistoimijuutta monitoimijaisessa verkostossa. Tätä yksilöllistä ja yhteistä kehittämistoimijuuden rakentumisen dynamiikkaa on aikuiskasvatustieteellisen tutkimuksen ja kehittävän työntutkimuksen piirissä tehty vasta vähän (Haapasaari 2020). Tutkimuksemme tekee näkyväksi tämän hienovaraisen dynamiikan.

Yksilöllisen toimijuuden analysointi kollektiivisten kehittämistekojen tunnistamisen rinnalla on interventioprosessin ja sen vaikuttavuuden ymmärtämisen kannalta vastaisuudessa suositeltavaa. Aiemmista tutkimuksista koostamamme analyysikehys (taulukko 1) sekä yksilöä seuraava narratiivinen analyysi olivat tähän toimivia analyysitapoja. Interventioissa tulisi tulevaisuudessa kiinnittää huomiota siihen, miten kokeilu tai käytäntö näkyisi kaikkien toimijoiden teoissa, ei vain sen, joka ensimmäisenä ilmoittautuu hoitavansa asian. Fasilitoijalta tämä vaatii herkkyyttä ja sosiaalisen prosessin havainnointia.
Kehittämistoimijuuden epätasaista jakautumista yksilöiden kesken voi olla vaikea havaita itse interventiotilanteessa. Vasta jälkikäteinen analyysi kaikista ryhmäkeskusteluista voi tehdä kehittämistoimijuuden eri teot näkyviksi. Vienon puheessa esiintyi runsaasti oman toimijuuden vahvistamista, rajaamista ja toimijuuden laajentamispyrkimyksiä omana kehittämistoimijuustekotyyppinään (ks. Heikkilä \& Seppänen 2014). Puheen kohteena ei tällöin ollut pelkästään itse kehitettävä kokeilu vaan se, kenen pitäisi toimia ja miten. Tutkimuksemme perusteella minä- ja mä- vs. me-sanat vuorovaikutuksessa indikoivat suuntaa-antavasti sitä, missä määrin osallistujat ilmaisevat vievänsä tekoja itse ja missä määrin yhteisesti käytäntöön. Tämä voi olla jatkossakin nopea menetelmä selvittää yksilöllisen ja yhteisen toimijuuden suhdetta jo interventioprosessin kuluessa.

Analyysin esiin piirtämä yksilöllisen kehittämistoimijuuden vahvuus ja sen epätasainen jakautuminen kouluttajan, johdon, työpaikan edustajan ja opiskelijan kesken herättivät kysymyksiä siitä, olisivatko fasilitoijat voineet puuttua eri toimijoiden välisiin

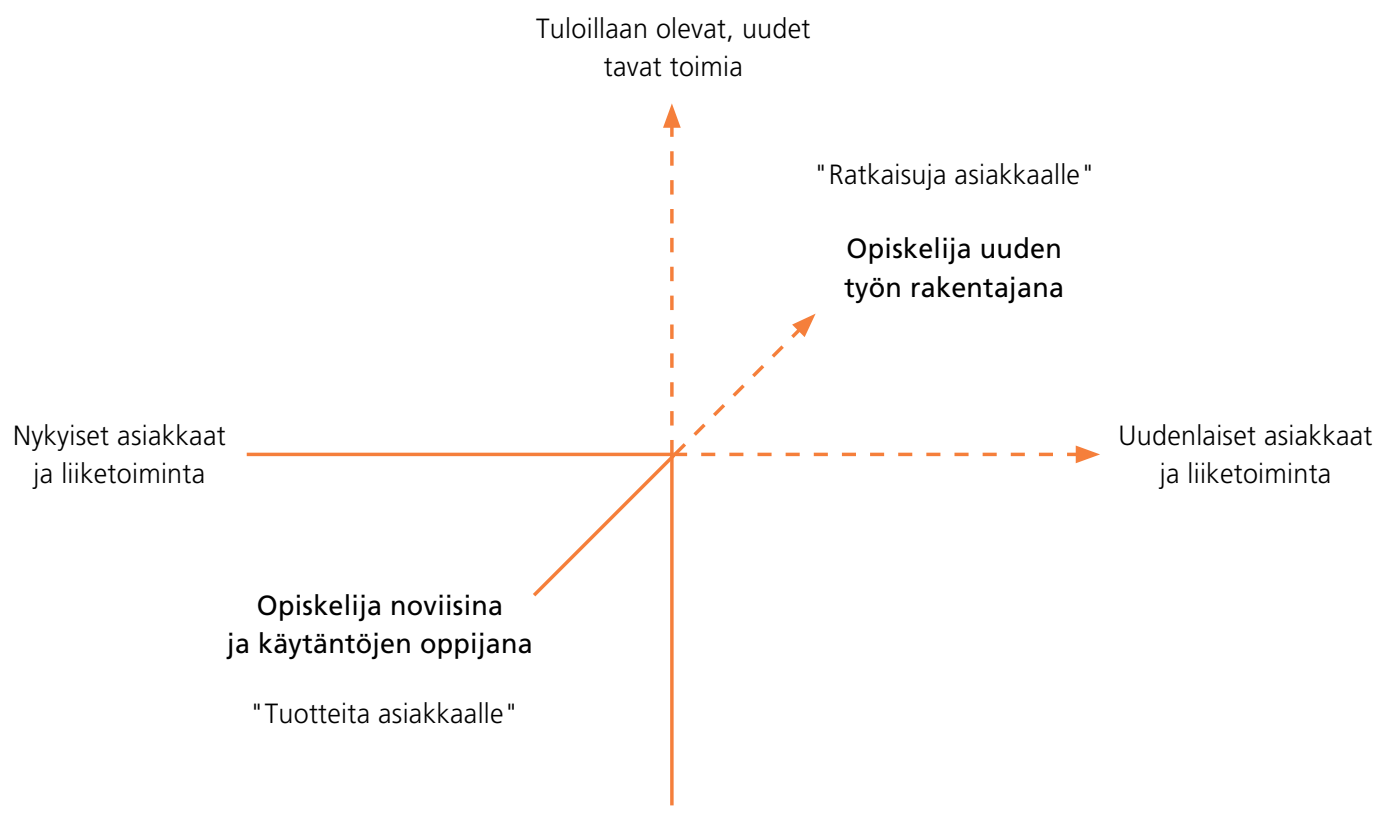

Nykyiset tavat toimia

Kuva 5. Kehityskartta kolmiulotteisena toiminnan sekä oppimisen tavan muutoksena. 
suhteisiin, valta- ja ennakkoasetelmiin paremmin jo muutospajojen aikana.

Muutospajamenetelmässä fasilitoijan pääasiallinen rooli on ollut tukea kollektiivista kehittämistoimijuutta ja oppimista kahden virikkeen menetelmän avulla. Varsinkin monen toimijan välisten interventioiden toteuttamisessa on tulevaisuudessa kiinnitettävä yhä enemmän huomiota siihen, keiden toimijuutta tulisi vahvistaa ja tukea, jotta käytännöstä tulisi kestävä. Uuden käytännön vakiinnuttaminen vaatii yksilön tekojen lisäksi käytännön levittämistä yhteisillä areenoilla ja ujuttamista osaksi vallitsevaa toimintapolitiikkaa tai käytäntöä (ks. Saari, Lehtonen \& Toivonen 2015).

Vakiinnuttamisen vaiheessa fasilitoija olisi voinut ohjata kouluttajaa ja työpaikkoja tekemään opiskelijan toimijuutta vahvistavan työkalun, jonka avulla opiskelija itse olisi voinut olla päävastuussa työpaikan ja oppilaitoksen yhteistyön organisoinnista työharjoittelunsa aikana (vrt. Engeström 2007). Tämä olisi tukenut opiskelijan roolin siirtymistä oppimisen kohteena olemisesta kohti uuden työn rakentajan roolia. Sivusta kehittämistekoja kannustanut HRtoimija olisi voinut dokumentoida, viestiä ja levittää käytäntöä muualle oppilaitosten ja työpaikkojen välisiin suhteisiin. Kaiken kaikkiaan verkostomaisessa interventiossa kokeilun jatkuvuutta tulisi siis pohtia erikseen jokaisen osallistujan oman toiminnan kontekstissa; tässä tapauksessa oppilaitoksen, työpaikkojen, opiskelijan sekä henkilöstöhallinnon.

Kehityskartta mallinsi kaupan alan liiketoiminnan kehityksen tulevaa suuntaa, mutta oppimisen tavan muutos jäi muutospajassa vähemmälle huomiolle. Moniulotteisissa verkostomaisissa interventioissa kehityskarttaa voisi mallintaa kolmiulotteisesti niin, että myös oppimisen tavan muutos näkyisi yhtenä ulottuvuutena (kuva 5).

Siirtymä vanhojen toimintamallien omaksumisesta kohti uusien toimintamallien yhteistä kehittelyä ja uuden työn rakentamista (kuten Gherardi, Nicolini \& Odella 1998) jäi muutospajan välineistä puuttumaan ja teoretisoimatta. Tämä vanhan ja uu- den oppimisen jännite vasta pilkahti toimijoiden välisessä vuorovaikutuksessa.

Ammatillisen koulutuksen reformin tavoite opiskelijan muuttumisesta käytäntöjen omaksujasta aktiiviseksi uuden työn rakentajaksi vaatii kaikkien osapuolten toimintatapojen muutosta sekä opiskelijan valtuuttamista uuden työn muutosagentiksi. Muutospajamenetelmä voi parhaimmillaan antaa hyvän ponnistuslaudan muutokseen. Tämä edellyttää yhteisen oppimisen lisäksi yksilöiden kehittämistoimijuuden ja siitä seuraavien tekojen tukemista työpaikoilla sekä oppilaitoksissa.

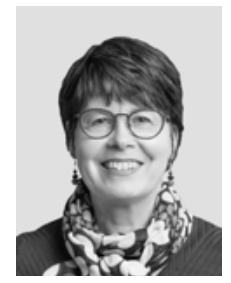

EVELIINA SAARI

FT, aikuiskasvatuksen dosentti, johtava tutkija Työterveyslaitos

(D) https://orcid.org/0000-00034710-8011

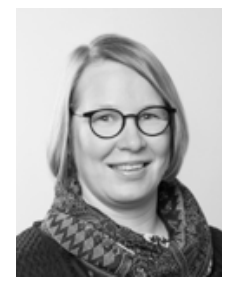

ANNA-LEENA KURKI

$K M$, erityisasiantuntija

Työterveyslaitos

(iD https://orcid.org/0000-00031125-4949

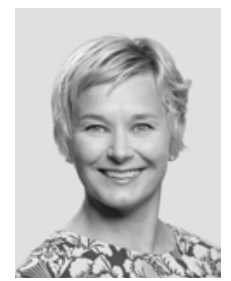

PAULIINA MATTILA-HOLAPPA

PsT, vanhempi asiantuntija Työterveyslaitos

(D) https://orcid.org/0000-00027202-2386

Artikkeli on kirjoitettu osana Euroopan sosiaalirahaston (ESR) rahoittamaa Ammattitaitoa yhdessä - työyhteisöt ja oppilaitokset tukemassa ammattiin oppijan sujuvia siirtymiä -projektia (2018-2020). Lämmin kiitos kaikille hankkeen muutospajojen osallistujille. Kiitos myös kahdelle anonyymille arvioitsijalle ja Aikuiskasvatuksen toimituskunnalle arvokkaista, artikkelin käsikirjoitusta eteenpäin vieneistä kommenteista. 
Ahonen, H., Virolainen, L. \& Gardemeister, S. (2020). Havahdu oppimaan alati kehkeytyvää - oppimisesta kompleksisessa työelämässä. Teoksessa P. Vartiainen \& H. Raisio (toim.) Johtaminen kompleksisessa maailmassa. Helsinki: Gaudeamus, 229-248.

Amistutkimus 2018. Ammatillisen koulutuksen reformi. https://www.amistutkimus.fi/ammatillisenkoulutuksen-reformi/ (8.6.2020).

Edwards, A. (2012). The role of common knowledge in achieving collaboration across practices. Learning, Culture and Social Interaction 1(1), 22-32. https:// doi.org/10.1016/j.Icsi.2012.03.003

Engeström, Y. (1987). Learning by expanding. An Activity-theoretical approach to developmental research. Helsinki: Orienta-Konsultit.

Emirbayer, M. \& Mische, A. (1998). What is agency? The American Journal of Sociology 103(4), 962-1023.

Engeström, Y. (1994). Training for change: new approach to instruction and learning in working life. Geneva, Switzerland: ILO.

Engeström, Y. (2007a). Putting Vygotsky to work: The Change Laboratory as an application of double stimulation. Teoksessa H. Daniels, M. Cole \& J. Wertsch (toim.) The Cambridge Companion to Vygotsky. Cambridge: Cambridge University Press, 363-382.

Engeström, Y. (2007b). From Stabilization Knowledge to Possibility Knowledge in Organizational Learning. Management Learning 38(3), 271-275.

Engeström, Y. \& Sannino, A. (2011). Discursive manifestations of contradictions in organizational change efforts. Journal of Organizational Change Management 24(3), 368-387.

Eteläpelto, A. (2017). Emerging conceptualisations on professional agency and learning. Teoksessa M. Goller \& S. Paloniemi (toim.) Agency at Work. Agentic Perspective on Professional Learning and Development Cham: Springer, 183-201. https://doi. org/10.1007/978-3-319-60943-0_10

Eteläpelto, A., Vähäsantanen, K., Hökkä, P. \& Paloniemi, S. (2014). Miten käsitteellistää ammatillista toimijuutta työssä? Aikuiskasvatus, 34(3), 202 - 214. https://doi.org/10.33336/aik.94100

Filliettaz, L. (2011). Collective guidance at work: a resource for apprentices? J Voc Educ Work 63(3), 485-504.

Gherardi, S. (2018). Practices and knowledges. Teoria a Prática em Administracao 8(2), 33-59. http:dx.doi. org/10.21714/38-104X2018v8i2S-38857

Gherardi, S., Nicolini, D. \& Odella, F. (1998). Toward a social understanding of how people learn in organisations: the notion of situated curriculum. Management Learning 29(3), 1-34.
Gorli, M., Nicolini, D. \& Scaratti, G. (2015). Reflexivity in practice: Tools and conditions for developing organizational authorship. Human Relation 68(8), 347-375.

Guile, D., \& Griffiths, T. (2001). Learning through work experience. Journal of Education and Work 14(1), 113-131.

Haapasaari, A. (2020). The hunters of lost parcels. An activity-theoretical study of the emergence and sustainability of workers' transformative agency. Helsinki Studies in Education 86. Helsinki: Unigrafia.

Haapasaari, A., Engeström, Y. \& Kerosuo, H. (2014). The emergence of learners' transformative agency in a Change Laboratory intervention. Journal of Education and Work 26(2), 232-262. http://dx.doi. org/10.1080/13639080.2014.900168.

Hasu, M. (2005). In search of sensitive ethnography of change: Tracing the invisible handoffs from technology developers to users. Mind, Culture and Activity 12(2), 90-112.

Heikkilä, H. \& Seppänen, L. (2014). Examining developmental dialogue: the emergence of transformative agency. Outlines-Critical Practice Studies 15(2), 5-30.

Jokinen, J., Lähteenmäki, L. \& Nokelainen, P. (2009). Työssäoppimisen lumo. Tiivistelmä toisen asteen ammatillisen sekä ammatillisen korkeaasteen koulutuksen ja työelämän yhteistyön metatutkimuksesta. Opetusministeriön julkaisuja 2009:10. Helsinki: Yliopistopaino.

Kerosuo, H. (2014). Kollektiivinen muutostoimijuus - esimerkkinä solmutyöskentely rakennusalan kehittämishankkeessa. Aikuiskasvatus 34(3), 178191. https://doi.org/10.33336/aik.94098

Laajala, T. (2016). Ammattikorkeakoulun osaamisperustaisen opetussuunnitelman tulkintarepertuaarit. Aikuiskasvatus 36(4), 294-302. DOI: https://doi.org/10.33336/aik.88515

Lehtonen, E., Rintala, H., Pylväs, L. \& Nokelainen, P. (2018). Ammatillisten opettajien näkemyksiä opettajan työssä tarvittavasta kompetenssista ja työelämäyhteistyöstä. Ammattikasvatuksen aikakauskirja 20(4), 10-26.

Mauno, S., Minkkinen, J., \& Auvinen, E. (2019). Nakertaako työn intensiivisyyden lisääntyminen työssä suoriutumista ja työn merkityksellisyyttä? Vertaileva tutkimus eri ammattialoilla. Hallinnon tutkimus 38(4), 271-289.

Rintala, H. \& Nokelainen, P. (2019). Vocational Education and Learners' Experienced Workplace Curriculum. Vocations and Learning. https://doi. org/10.1007/s12186-019-09229-w 
Rintala, H., Mikkonen, S., Pylväs, L., Nokelainen, P. \& Postareff, L. (2015). Työpaikalla tapahtuvaa oppimista ja ohjausta edistävät ja estävät tekijät. Ammattikasvatuksen aikakauskirja 17(4), 9-21.

Saari, E., Hasu, M., Käpykangas, S. \& Kovalainen, A. (2020). Emergence of agentic professional competence in the digitalization of social services and health care. Teoksessa S. Poutanen, A. Kovalainen \& P. Rouvinen, P. (toim.) Digital work and the platform economy. New York \& London: Routledge.

Saari, E., Lehtonen, M. H. and Toivonen, M. (2015). Making bottom-up and top-down processes meet in public innovation. The Service Industries Journal 6 (35), Creativity and Innovations in Services, 325-344.

Töytäri, A., Tynjälä, P., Vanhanen-Nuutinen, L., Virtanen, A. \& Piirainen, A. (2019). Työelämäyhteistyö ammattikorkeakouluopettajan osaamishaasteena. Ammattikasvatuksen aikakauskirja 21(1), 14-30.

Vanhanen-Nuutinen, L. \& Laitinen-Väänänen, S. (2018) Mitä hyötyä on ammattikorkeakoulun ja työelämän yhteistyöstä? Teoksessa A. Mutanen, P. Houni, J. Mäntyvaara \& M. Kantola (toim.) Hyöty. Turun ammattikorkeakoulun tutkimuksia 48, 166-177.

Virkkunen, J. \& Newnham, D. S. (2013). The Change Laboratory. A Tool for Collaborative Development of Work and Education. Rotterdam: Sense Publishers.

Vygotsky, L. S. (1978). Mind in society: The psychology of higher psychological processes. Cambridge, MA: Harvard University Press.

Vygotsky, L. S. (1986) Thought and language. Cambridge, MA: MIT Press. 